\title{
Professional education in the digital transformation society
}

\section{La educación profesional en la sociedad de la transformación digital}

\author{
Olga I. Vaganova \\ vaganova_o@rambler.ru \\ https://orcid.org/0000-0001-8347-484X \\ Minin Nizhny Novgorod State Pedagogical University, Nizhny Novgorod, Russia. \\ Lyubov I. Kutepova \\ lubovkutepova@mail.ru \\ https://orcid.org/0000-0002-3175-4978 \\ Minin Nizhny Novgorod State Pedagogical University, Nizhny Novgorod, Russia. \\ Zhanna V. Smirnova \\ Z.v.smirnova@mininuniver.ru \\ https://orcid.org/0000-0001-9950-9824 \\ Minin Nizhny Novgorod State Pedagogical University, Nizhny Novgorod, Russia. \\ Marina N. Bulaeva \\ bulaevamarina@mail.ru \\ https://orcid.org/0000-0002-9928-9451 \\ Minin Nizhny Novgorod State Pedagogical University, Nizhny Novgorod, Russia. \\ Evgeniy L. Bobylev \\ arzjen@mail.ru \\ https://orcid.org/0000-0003-4416-5707 \\ National Research Lobachevsky State University of Nizhny Novgorod, Arzamas branch, \\ Russia.
}

\section{Abstract}

Aceptado: 28/10/21

Purpose of the article is analysis of the experience of training students in the context of digital transformation. The article presents the dynamics of the development of online schools at the global level, highlights the main goals of using electronic educational resources. The respondents were presented with the variety of answer options. The most common were selected and put into a separate diagram. Results says the development of online education is being carried out at a high rate both in Russia and at the global level. Digital transformation gives rise to the demand for the development of new professions directly related to electronic instruments. Based on the data obtained, first of all, there is a need for specialists who are ready for high-quality teaching of students in the online space. The variety of electronic educational resources expands the 
Olga I. Vaganova, Lyubov I. Kutepova, Zhanna V. Smirnova, Marina N. Bulaeva, Evgeniy L. Bobylev.

opportunities for their training and focuses professional education on new reform processes.

Key words: digital transformation, vocational education, distance learning, online schools, electronic technologies.

\section{Resumen}

El objeto del artículo es el análisis de la experiencia de formar estudiantes en el contexto de la transformación digital. El artículo presenta la dinámica del desarrollo de las escuelas en línea a nivel global, destaca los principales objetivos del uso de recursos educativos electrónicos. A los encuestados se les presentó una variedad de opciones de respuesta. Se seleccionaron los más comunes y se colocaron en un diagrama separado. Los resultados dicen que el desarrollo de la educación en línea se está llevando a cabo a un ritmo elevado tanto en Rusia como a nivel mundial. La transformación digital genera la demanda de desarrollo de nuevas profesiones directamente relacionadas con los instrumentos electrónicos. Con base en los datos obtenidos, en primer lugar, se necesitan especialistas que estén preparados para una enseñanza de alta calidad de los estudiantes en el espacio en línea. La variedad de recursos educativos electrónicos amplía las oportunidades para su formación y enfoca la educación profesional en nuevos procesos de reforma.

Palabras clave: transformación digital, educación vocacional, educación a distancia, escuelas en línea, tecnologías electrónicas.

\section{Introduction}

The digital transformation process encourages vocational education system to adapt to modern conditions. Continuous innovative development is an incentive for professional educational institutions to find effective, appropriate to the situation, ways to form competitive specialists, ways to prepare for professional activities that will be in demand in the long term.

The development of electronic technologies is actively supported by the state. From September 1, 2020 to December 31, 2022, an experiment is being conducted to introduce a target model of a digital educational environment, which makes it possible to implement educational programs using electronic educational technologies.

Today, normative documents are being actively developed that regulate in detail the activities associated with introduction of digital educational content.

As part of the implementation of the Decree of the President of the Russian Federation of May 7, 2018 No. 204 "On national goals and strategic objectives of the development of the Russian Federation for the period until 2024 and the Decree of 21.07.2020 No. 474" On the national development goals of the Russian Federation for the period until 
$2030 "$ the issue of ensuring accelerated introduction and implementation of digital technologies is being addressed.

The National Program "Digital Economy of the Russian Federation" is implementing several projects that focus on regulatory regulation of digital educational activities, personnel for the digital economy, information infrastructure and security, digital technologies and artificial intelligence.

Order of the Ministry of Education of Russia dated 11.08.2021 No. 543 "On approval of the criteria and procedure for the examination of digital educational content and educational services offered by providers of content and educational services within the digital educational environment" approves the procedure for testing various educational services.

Order of the Ministry of Education of Russia dated 11.08.2021 No. 545 "On approval of requirements for functional, technical characteristics and parameters of digital educational content units, for educational services" discloses in detail the regulations for the implementation and use of digital educational content (Smirnova et al., 2020).

Today, professional educational institutions use various digital tools in their activities (Shashlo et al., 2018). The training of students is accompanied by the inclusion of electronic platforms, online broadcasts via Zoom, Skype or Google Duo, VR glasses, simulation programs, document cameras and others.

It is necessary to note the features of the educational process that arose as a result of social changes (Kiseleva et al., 2019). The 2020 pandemic has exacerbated issues of distance learning, the use of electronic tools in order to maintain social distance and prevent threats to the life and health of citizens (Dobudko et al., 2019). The consequences of the decisions made in the crisis conditions were the development of online courses and schools. The distance educational process has become more developed.

There is a need for specialists who are able to organize a high-quality distance educational process. The training of modern specialists in the field of education is carried out by a professional education teacher. In modern conditions, he must have competencies related to the implementation of information technology for conducting classes in an online format and providing students with material in electronic form.

In these conditions, we are talking about the teacher of vocational training as a profession of the future, which is already in high demand today (Aniskin et al., 2020). Teaching students through the use of the Internet has a special specificity.

Today, it is required to monitor the development of the digital educational space in order to implement a prompt response of educational institutions to emerging changes. 


\section{Theoretical framework}

The introduction of digital technologies in vocational education is carried out in order to intensify, improve the quality of the educational process, in order to fulfill a social order in the context of informatization, globalization and mass communication, in order to develop the student's personality and prepare him for a comfortable life (Mazanyuk et al., 2020).

Traditionally, vocational education implies a fusion of theoretical and practical training (Demidov et al., 2020). The issue of organizing practical classes for lawyers, designers, economists, builders and other students in a remote format is solved by the introduction of electronic simulators that provide imitation of professional activities.

The didactic possibilities of digital transformation include: the implementation of an interactive dialogue (Vaganova et al., 2020); visualization of educational material (Kharytonov et al., 2019); graphic interpretation of various patterns (Pichugina \& Bondarchuk, 2019); informatization of educational activities management processes and control of results; simulation of real and virtual processes (Kidina, 2020). Electronic instruments act as tools that simulate the operation of laboratory stands and machines (Tsarapkina et al., 2021).

These are new opportunities that other learning tools do not have, opportunities for constant feedback.

Digital tools allow future designers to step into a room and see it from the inside. Virtual reality glasses allow them to build a project more carefully (Yarygin et al., 2019). It is easier for a teacher to give a technical task. Through the program, the student can increase or decrease the object (Vaganova et al., 2019). For future surveyors or geologists, it becomes possible to trace the growth or destruction of mountains, the disintegration of the core (Pinkovetskaia et al., 2020). Flight simulators are used to train pilots (Savka et al., 2020).

For teachers of both humanitarian and natural sciences, technical disciplines, such tools are not enough, since it is necessary to conduct laboratory, practical exercises (Samerhanova, 2019).

The pre-digital era characterized the student as a consumer. But now, when we use a variety of technologies, we are talking about training a creative specialist (Akvazba et al., 2019). All the necessary information is on the Internet. A person should be able to use tools to search for it, generate new knowledge, systematize, analyze the correctness of certain judgments about one event and draw his own conclusion, that is, think critically. Nowadays, when a large amount of information needs to be processed, critical thinking becomes very important (Ponachugin \& Lapygin, 2019). And this is one of the main results of digital transformation in terms of the personal and professional development of the student (Shcerbakova \& Shcerbakova, 2019). 
As the trend towards the use of innovative technologies in education is becoming more and more popular, online schools are becoming more, then the demand for teachers of vocational training is increasing (Bulaeva, et al., 2018). Therefore, we can talk about the profession of a teacher of vocational training as a profession of the future, a profession, the transformation of which is closely related to digital transformation (Ivanova \& Korostelev, 2019).

The vocational education teacher must have the skills to:

- communication in the digital environment (Klinkov, 2020);

- cooperation in the digital environment (Nagovitsyn et al., 2020);

- professional self-improvement in conditions of uncertainty;

- information data management (Vaganova et al., 2019).

It is necessary to note the condition of compliance with the safety of communications, which is disclosed in more detail in the table.

\section{Table 1.}

Contents of the safety conditions of communications.

Communication security

Communication is a specific connection between the subjects of the educational process, which is the interrelated stages of working with information.

Information security - protection of the information system from outside interference (accidental or deliberate), which has a negative impact on the owners (s) or users of information.

\begin{tabular}{|c|c|c|}
\hline \multicolumn{3}{|c|}{ Safety principles } \\
\hline Confidentiality & Availability & Integrity \\
\hline $\begin{array}{l}\text { The privacy policy applies } \\
\text { to all personal information, } \\
\text { such as last name, first } \\
\text { name, patronymic, date of } \\
\text { birth, photo, contact } \\
\text { numbers, address, place of } \\
\text { work and place of } \\
\text { residence, etc. }\end{array}$ & $\begin{array}{l}\text { Providing the opportunity } \\
\text { for each student to use the } \\
\text { information available on the } \\
\text { corresponding course, } \\
\text { ensuring the availability of } \\
\text { correspondence with the } \\
\text { teacher and fellow students }\end{array}$ & $\begin{array}{l}\text { The real functioning of the } \\
\text { system is achieved due to } \\
\text { the formed system of } \\
\text { goals, methods and } \\
\text { teaching aids }\end{array}$ \\
\hline
\end{tabular}

A modern teacher of vocational training in the context of digital transformation, carrying out activities remotely, must have the knowledge of the methodologist of online courses, that is, create high-quality courses within the framework of an online school, administer and supervise them. 


\section{Methodology}

This article presents a study by TalentTech, Netology and EdMarket (large companies specializing in full-cycle online education). For six months, the expert group studied several segments of the world education industry (higher education, school, lifelong learning, preschool and corporate education), as well as investment activity. This is the second global survey of the online education market. The first was held in 2017.

In the study, we focused on the goals that students of online schools are pursuing in 2020 and recorded the main answers.

A specially designed survey was conducted for students, which shows the main educational goals. The research was carried out in several stages. At the first stage, a questionnaire was developed for the student audience. Further, the collection of data was carried out in electronic format. The most frequent answers were statistically processed. At the third stage, the results were formed into a single table and presented graphically.

\section{Results and discussion}

The global education market has undergone major transformations. The spread of online education is gaining momentum.

The figure highlights the forecast for the use of online education in various sectors.

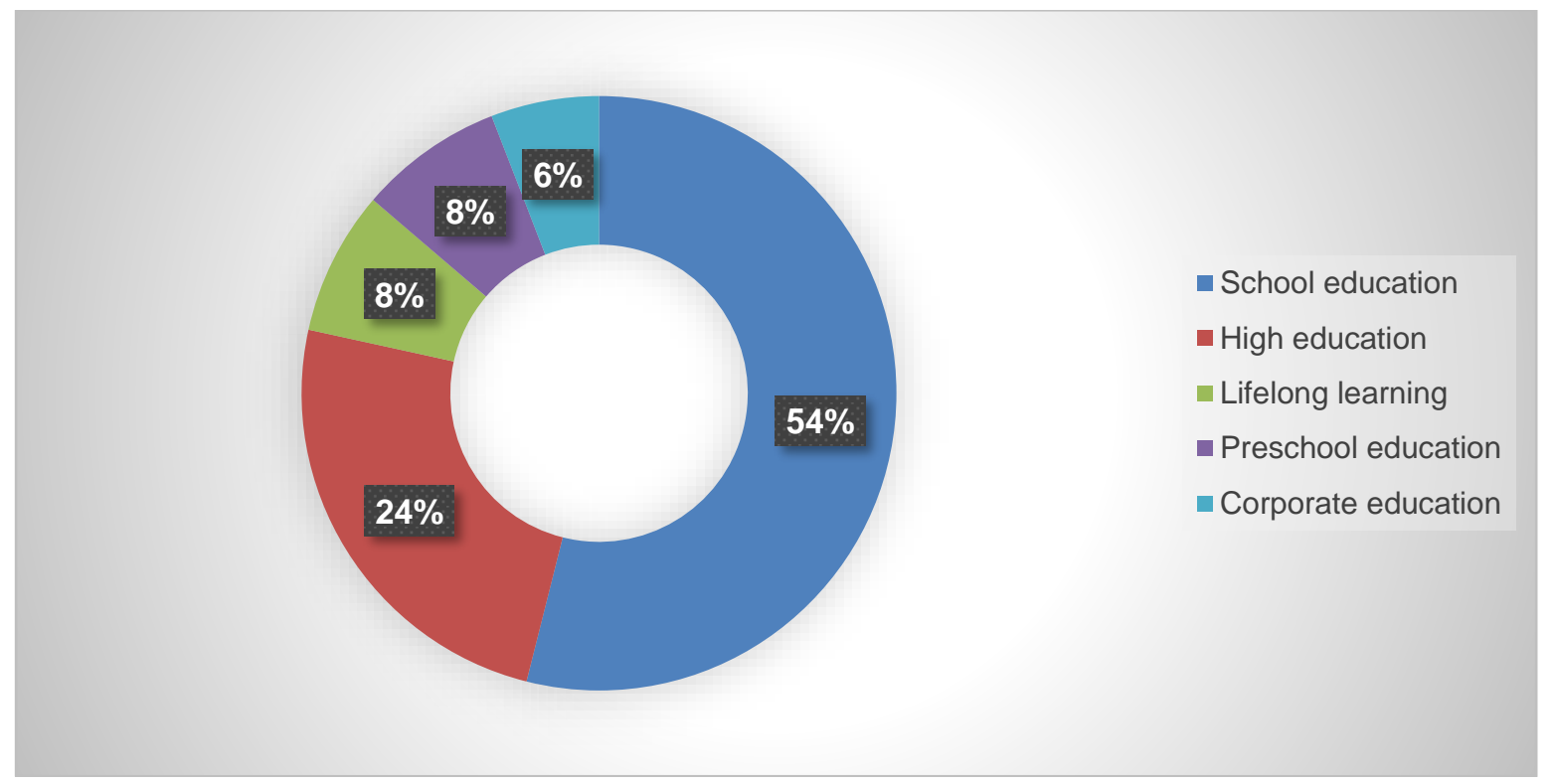

Fig. 1. Forecast for the structure of the global education market by 2030 .

We see that school education occupies a leading position, followed by higher education, followed by lifelong learning, preschool and corporate education. 
According to forecasts, the demand for online education will only increase, therefore, the relevance of training relevant specialists who are ready, in turn, to carry out training in the online space, is confirmed.

In the study, we focused on the goals pursued by the students of online schools. We have highlighted the main answers in the figure.

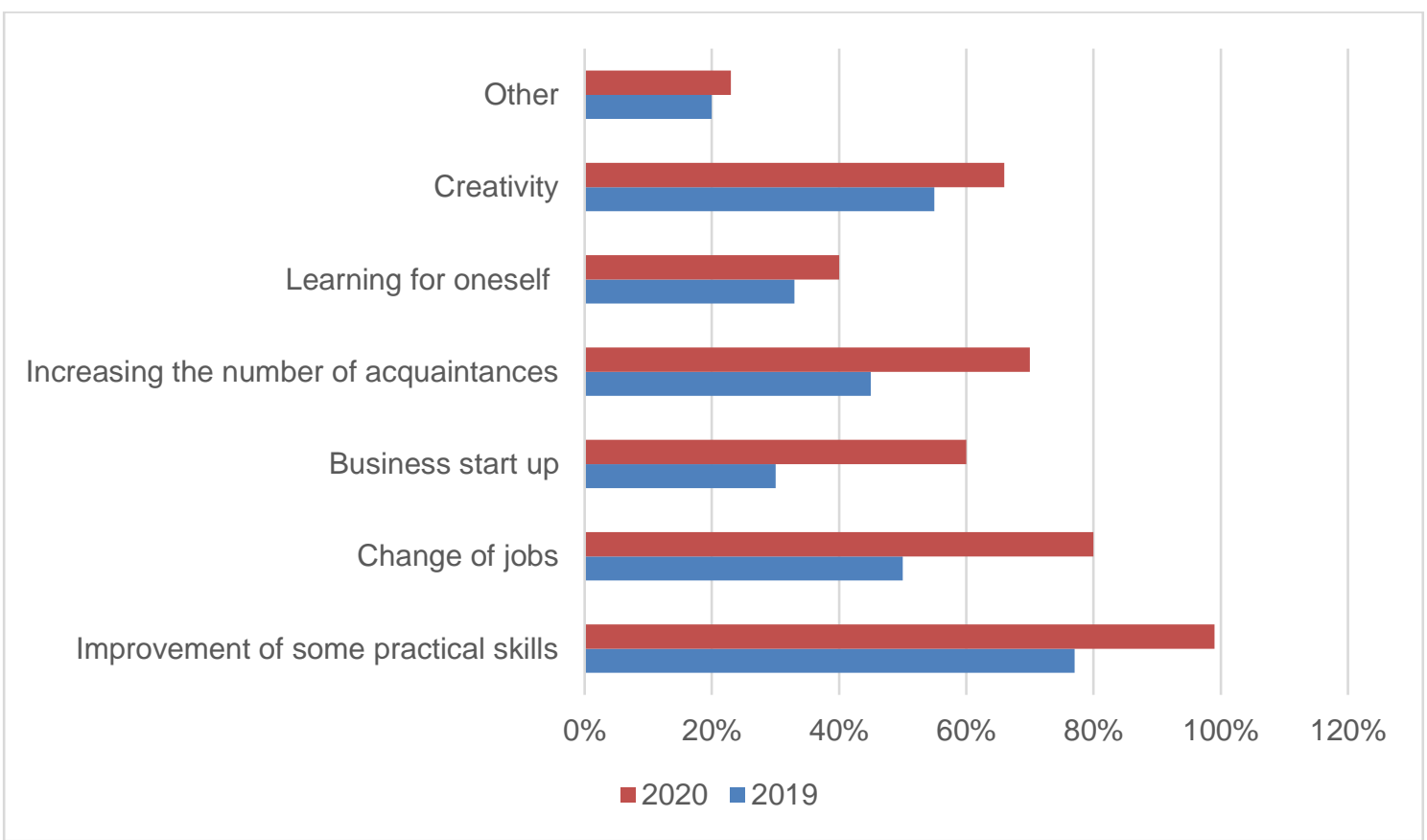

Fig. 2. Learning Objectives in Online Schools.

In general, each of the indicators presented by 2020 has become higher. In the unfolding social conditions, the most urgent were the improvement of individual practical skills and a change of profession.

The professional education teacher, as a professional of the future, should be guided by consumer needs, relying on statistical data, on forecast data. The online education market is growing and the need for specialists will also grow over time.

\section{Conclusions}

In the context of digital transformation, vocational education is becoming more visual, effective and mobile. Today there are many questions and difficulties to be overcome. However, it should be said that the great potential of the available opportunities allows us to form an idea of how much electronic technologies are in demand and how they are reflected in the future of professional activity. 
Education acquires a number of features that are associated with remote learning and the use of innovative means of training students, such as simulators, electronic, programs, virtual reality glasses, and more.

Today we cannot talk about the complete replacement of traditional education with distance education, however, the introduction of information technologies is carried out at a high pace. And the addition of the educational process with electronic tools allows students to engage and make them active subjects of learning, to form a readiness for independent mastering of the material, quick adaptation to innovative changes. The future of vocational education is closely related to information technology.

Today, educational institutions are developing professional competencies and soft skills that will allow students to adapt to the professions of the future.

Based on the results of the study, we can say that one of the main professions of the future is becoming a professional education teacher who is able to build a competent educational process in a distance setting.

Today, the majority of students using online education note that it is important for them to improve certain professional skills. And teachers of online courses, online schools allow them to achieve their goals.

\section{Bibliographic references}

Akvazba, E., Bogdanova, V., Uzlova, N., \& Patrusheva, I. (2019). Problems and prospects of the Russian information society. Amazonia Investiga, 8(20), 310-322. Retrieved from https://amazoniainvestiga.info/index.php/amazonia/article/view/144.

Aniskin, V. N., Korostelev, A. A., Lvovna, B. A., Kurochkin, A. V., \& Sobakina, T. G. (2020). Teaching potential of integrated learning technologies Smart, Stem and Steam. Revista De La Universidad Del Zulia, 11(29), 328-336.

Arbeláez-Campillo, D., Tatsiy, V., Rojas-Bahamón, M., \& Danilyan, O. (2020). Contributions of critical thinking as a form of participation and political deliberation. Amazonia Investiga, 9(27), 5-12. https://doi.org/10.34069/Al/2020.27.03.1

Bulaeva, M. N., Vaganova, O. I., Koldina, M. I., Lapshova, A. V., Khizhnyi, A.V. (2018). Preparation of Bachelors of Professional Training Using MOODLE. Advances in intelligent systems and computing, 622, pp. 406-411.

Dobudko, T.V., Korostelev, A.A., Gorbatov, S.V., Kurochkin, A.V., \& Akhmetov, L.G. (2019). The organization of the university educational process in terms of digitalization of education. Humanities and Social Sciences Reviews. 7(4), pp. 1148-1154.

Demidov, A., Syrina, T., \& Tretyakov, A. (2020). Development of Digital Skills and Media Education System: From the Organization of Environmental Education of Preschool Children to the ICT Competence of Teachers. Media Education (Mediaobrazovanie), $1, \quad \mathrm{pp} . \quad 11-23$. http://ejournal53.com/journals_n/1584456608.pdf 
Decree of the President of the Russian Federation No. 204, "On national goals and strategic objectives of the development of the Russian Federation for the period until 2024 and the Decree of 21.07.2020 No. 474" of May 7, 2018. Date of the application: 25.09.2021. URL: http://www.kremlin.ru/acts/bank/43027.

Decree No. 474 "On the national development goals of the Russian Federation for the period until 2030" of 21.07.2020. Date of the application: 23.08.2021. URL: http://publication.pravo.gov.ru/Document/View/0001202007210012

Ivanova, N., \& Korostelev, A. (2019). The impact of competitive approach on students' motivation in sport. Amazonia Investiga, 8(18), 483-490. Retrieved from https://amazoniainvestiga.info/index.php/amazonia/article/view/362

Kidina, I. M. (2020). Management of the pedagogical collective in the conditions of implementing distance learning. Baltic Humanitarian Journal. (Baltic Humanitarian Journal). Vol. 9 No 4 (33), pp. 93-96.

Klinkov, G. T. (2020). The nature of pedagogical communication within the boundaries of systematic technological training. Scientific Vector of the Balkans, 4 (2 (8)), 11-13. URL: https://sci-vector-balkans.com/wp-content/uploads/2020/11/SVB-2020-T.428-2.pdf

Kharytonov, E., Kharytonova, O., Tolmachevska, Y., Fasii, B., \& Tkalych, M. (2019). Information Security and Means of Its Legal Support. Amazonia Investiga, 8(19), 255-265. https://amazoniainvestiga.info/index.php/amazonia/article/view/227

Kiseleva, O., Lebedev, A., Pinkovetskaia, I., Rojas-Bahamón, M., \& Arbeláez Campillo, D. (2019). Specialization and concentration of small and medium enterprises employees: Russian data. Amazonia Investiga, 8(20), 6-15. Retrieved from https://amazoniainvestiga.info/index.php/amazonia/article/view/59

Mazanyuk, E.F., Tretyakov, A.L., \& Amichba, L.R. (2020). Game technologies as a tool of motivation and improvement the quality of university students' training. SHS Web of Conferences: International Scientific and Practical Conference «Teacher Professionalism: Psychological and Pedagogical Support of a Successful Career» (ICTP 2020), Yalta, Russia, October 21-23, 2020. Vol. 87. 00108. https://www.shsconferences.org/articles/shsconf/abs/2020/15/shsconf_ictp2020_00108/shsconf_i ctp2020_00108.html

Nagovitsyn, R. S., Vaganova, O. I., Kutepov, M. M., M. L. N., Kosenovich, O. V, Moeseev, Yu. V., Vorotova, M. S., \& Osipov, A. Y. (2020). Interactive Technologies in Developing Student's Motivation in Physical Education and Sport. International Journal of Applied Exercise Physiology, 9(6), 78-85.

Order No. 543, "On approval of the criteria and procedure for the examination of digital educational content and educational services offered by providers of content and educational services within the digital educational environment", of the Ministry of Education of Russia dated 11.08.2021. Date of the application: 17.09.2021. URL: https://legalacts.ru/doc/prikaz-minprosveshchenija-rossii-ot-11082021-n-543-obutverzhdenii/.

Order No. 545 "On approval of requirements for functional, technical characteristics and parameters of digital educational content units, for educational services". Date of 
Olga I. Vaganova, Lyubov I. Kutepova, Zhanna V. Smirnova, Marina N. Bulaeva, Evgeniy L. Bobylev.

the application: 23.08.2021. URL: https://legalacts.ru/doc/prikazminprosveshchenija-rossii-ot-11082021-n-543-ob-utverzhdenii/.

Pichugina, G.A., \& Bondarchuk, A.I. (2019). Structure of the training case in the organization of the educational process. Humanitarian Balkan Research, 2(4), pp. 5-7.

Pinkovetskaia, I., Berezina, N., \& Sverdlikova, E. (2020). The main reasons for the exit of entrepreneurs from business. Amazonia Investiga, 9(26), 68-73. https://doi.org/10.34069/Al/2020.26.02.7

Ponachugin, A.V; Lapygin, Yu.N. (2019). Digital Educational Resources of the University: Design, Analysis and Expertise. Vestnik of Minin University, Vol. 7 (2), 5. (in Russ)

Shashlo, N., Petruk, G., \& Korostelev, A. (2018). Determinants of integration interaction among the subjects of the entrepreneurial innovation ecosystem of macro region. Amazonia Investiga, 7(13), 351-363. Retrieved from https://amazoniainvestiga.info/index.php/amazonia/article/view/569

Samerhanova, E.K. (2019). Formation of competences in the field of mathematical modeling among teachers of vocational training in the conditions of the information and educational environment of the university. Vestnik of Minin University, 2 (27), p. 1-7. Available at: DOI: 10.26795/2307-1281-2019-7-2-4. Access: May 23, 2021.

Savka, I. V., Yakymovych, T. D., \& Yaremko, T. I. (2020). Modern principles of professional education of humanities cycles in higher education institutions, Scientific Vector of the Balkans, 3 (9), 25-29. URL: https://cyberleninka.ru/article/n/suchasni-printsipi-profesiynospryamovanogonavchannya-distsiplin-gumanitarnogo-tsiklu-u-zakladah-vischoyi-osviti.

Smirnova, Z.V., Vezetiu, E.V., Vaganova, O.I., Pluzhnikova, E.A., Akimova, I.V. (2020). Automated knowledge management through e-testing. International Journal of Advanced Trends in Computer Science and Engineering, 9(3), pp. 3256-3260.

Shcerbakova, E.V., \& Shcerbakova, T. N. (2019). Experience of Use of Remote Computer Technologies at The Organization of Independent Work of Students in The Conditions of a Mark and rating system. Baltic Humanitarian Journal. (Baltic Humanitarian Journal), Vol. 8, No 4 (29), pp. 192-195.

Tsarapkina, J. M., Plahina, L. N., Konoplyuk, N. V., Vaganova, O. I., Lapshova, A. V. (2021). The formation of bachelors' digital competencies at the university. Propositos y representaciones, 9, № SI, Article number e811.

Vaganova, O.I., Korostelev, A.A., Smirnova, Z.V., Abramova, N.S., \& Dolmatov, S.N. (2019). Improving teachers' professionalism through the development of creativity. International Journal of Innovative Technology and Exploring Engineering, 8(8), pp. 630-634.

Vaganova, O. I., Petrozitskaya, I. A., Snatovich, A. B., Odarich, I. N., \& Kirillova, I. K. (2020). Heuristic technologies of training in professional education. Amazonia Investiga, 9(27), 509-517. https://doi.org/10.34069/Al/2020.27.03.55

Yarygin, O.N., Korostelev, A.A., Akhmetov, L.G., \& Maseleno, A. (2019). Modeling of competence as a tool of goal setting for education in modern society. International Journal of Recent Technology and Engineering, 7(6), pp. 72-77. 